UNIVERSITY OF GOTHENBURG

SCHOOL OF BUSINESS, ECONOMICS AND LAW

WORKING PAPERS IN ECONOMICS

No 616

\title{
Divergence in Stakeholders' Preferences: Evidence from a Choice Experiment on Forest Landscapes Preferences in Sweden
}

\author{
Anna Nordén, Jessica Coria, Anna Maria Jönsson, Fredrik \\ Lagergren and Veiko Lehsten
}

March 2015

ISSN 1403-2473 (print)

ISSN 1403-2465 (online) 


\title{
Divergence in Stakeholders' Preferences: Evidence from a Choice Experiment on Forest Landscapes Preferences in Sweden
}

\author{
Anna Nordén $^{\mathrm{a}, \mathrm{b}}$, Jessica Coria ${ }^{\mathrm{a}}$, Anna Maria Jönsson ${ }^{\mathrm{b}}$, Fredrik Lagergren ${ }^{\mathrm{b}}$, Veiko Lehsten ${ }^{\mathrm{b}}$ \\ ${ }^{a}$ Department of Economics, University of Gothenburg, Vasagatan 1, PO Box 640, SE 40530 Gothenburg, \\ Sweden \\ ${ }^{\mathrm{b}}$ Department of Physical Geography and Ecosystem Science, Lund University, Sölvegatan 12, SE 22362 Lund, \\ Sweden \\ E-mails: anna.norden@nateko.lu.se, jessica.coria@economics.gu.se, anna_maria.jonsson@nateko.lu.se; \\ fredrik.lagergren@nateko.lu.se and veiko.lehsten@nateko.lu.se. \\ Corresponding author: Jessica Coria, Department of Economics, University of Gothenburg, Vasagatan 1, PO \\ Box 640, SE 40530 Gothenburg, Sweden, +46 (0) 31786 4867, e-mail: jessica.coria@economics.gu.se
}

\begin{abstract}
A great deal of biodiversity can be found in private forests, and protecting it requires taking into consideration the preferences of key stakeholders. In this study, we examine and compare the valuation of forest attributes across the general public, private non-industrial forest owners and forest officials in Sweden by conducting a choice experiment. Our results indicate that citizens have a positive valuation of biodiversity protection. Moreover, their valuation is statistically higher than those of forest owners, implying that there is room for compensation. Interestingly, our results suggest that both forest owners and forest officials have a strong orientation towards production, with higher valuation than the general public of the common management practice of similar age and clear felling. Even though the Swedish Forestry Act regards production and environmental goals as equally important, we find that forest officials prefer management practices that promote production rather than biodiversity protection.
\end{abstract}

Keywords: biodiversity, choice experiment, forest, preference divergence JEL classification: D61, Q23, Q51 and Q58 


\section{Introduction}

Biodiversity plays a key role in sustaining the functioning of ecosystems and thus in the provision of ecosystem services. Since a great deal of biodiversity is found in private forests, the way in which these forests are managed has major implications for biodiversity. Unfortunately, the supply of biodiversity usually goes unrewarded by markets, and protecting it comes at an opportunity cost to forest owners. This makes it unlikely to achieve biodiversity protection in the absence of further incentives to compensate forest owners for the potential productivity losses.

In addition, biodiversity protection on private forest land is a complex policy area where several legitimate competing interests and actors influence the outcome (Gritten et al., 2013). Two key stakeholders are the general public and forest owners, and these two groups often have different interests and values concerning the importance attached to production on the one hand and biodiversity and recreational opportunities on the other. In order to design effective policies for protection of forest biodiversity and ecosystem services, a better understanding of the preferences of forest owners and the public is needed. ${ }^{1}$

However, preferences are endogenous and since forest policies in many countries are largely implemented through communication and personal contacts between forest owners and forest officials, it is likely that over time an understanding between the two groups is developed, narrowing the gap in preferences (Kindstrand et al., 2008). Further, forest officials are a heterogeneous group consisting of both public and private officials. In Sweden, for instance, forest owners generally have less contact with public forest officials today than a few years ago, and instead more contact with private officials at the forest owners' associations or in the forest industry (i.e., the timber buyers) (Jönsson and Gerger Swartling, 2014).

\footnotetext{
${ }^{1}$ The role of policy makers is also to take scientific information into account and to provide not only compromises but also policies that find support in, e.g., ecological principles.
} 
In this study, we examine forest values among different forest stakeholders in Sweden by conducting a choice experiment (CE) involving citizens, non-industrial private forest owners, and forest officials working for the government, forest companies, and forest owners' associations. Respondents were asked to choose among a set of productive forests shaped by alternative forest management practices, and thereby make trade-offs between management outcomes, biodiversity indicators, and costs. The specific research questions we aim to answer are: (i) Do different stakeholders have similar preferences for alternative forest management practices that lead to different biodiversity outcomes? (ii) Which dimensions of biodiversity (e.g., number of total or rare forest bird species) are valued the most? (iii) Are these dimensions valued the same across stakeholders?

Some previous studies have also examined forest values and beliefs among forest owners, the general public and forest officials in Sweden (see, e.g., Kindstrand et al., 2008; Nordlund and Westin, 2011; Eriksson, 2012; Eriksson et al., 2013; Hemström et al., 2014). These studies indicate that the interest groups have very heterogeneous preferences regarding biodiversity protection vs. production. For instance, in contrast to men/old people, women/young people value nature preservation higher than production (Nordlund and Westin, 2011; Eriksson et al., 2012). Also type of forest ownership and familiarity with the environmental goods affect preferences for biodiversity (see, e.g., Lidestav and Nordfjell, 2005; Eriksson, 2012; Eriksson et al., 2013).

A limitation of these studies is that they analyze values by means of rating and ranking tasks, which neither allows for a comparable measure of preferences (in a quantitative way) nor enables estimation of the willingness to pay (WTP) for various aspects of biodiversity protection. A CE provides a suitable framework for valuing preferences and has been used previously by Carlsson et al. (2011) and Rogers (2013) to compare citizens and EPA administrators in Sweden (marine reserves and clean air) and Australia (marine reserves), respectively. 
By using a CE approach, our study on forestry will not only allow us to estimate the preferences of different stakeholders, but also help guide the design of biodiversity policy in private forests by eliciting preferences for different components of biological biodiversity (e.g., total number of species, number of rare species, and geographical spread of biodiversity). $^{2}$

As pointed out by Nunes and van den Bergh (2001), most studies on biodiversity valuation fail to apply economic valuation to the entire range of biodiversity benefits, providing a very incomplete perspective on the value of biodiversity protection. In contrast, our study considers a broad range of biodiversity components and also provides empirical evidence on the tradeoffs/synergies between the delivery of ecosystem services (e.g., biomass production) and biodiversity protection. Better insights regarding the relations between the perceived values of biodiversity and ecosystem services will help with designing strategies and policy tools that maximize opportunities for conservation of multiple ecosystem services and biodiversity and thereby contribute to resource efficiency.

The remainder of the paper is organized as follows. Section 2 describes the forest management in Sweden today. Section 3 describes the design of our choice experiment and Section 4 presents the theoretical framework and model specification. Section 5 and Section 6 describe the data and the results, respectively, and finally Section 7 summarizes the paper and discusses some implications.

\section{Forest Management in Sweden}

In the Swedish society, the timber and pulpwood production is an important source of income with a total production value in 2011 of 23 billion EUR. The value added accounted for 2.2\% of GDP in the same year (Swedish Forest Agency, 2014). The focus on economic

\footnotetext{
${ }^{2}$ The design of biodiversity policy should also be based on a solid understanding of ecological processes and interaction among species. For instance, birds can influence the risk of insect outbreaks by acting as predators, and by quantifying this effect we may get an economic incentive to promote bird-friendly forest management, e.g., a forest with several tree species, and a mixture of size and age classes.
} 
profitability and timber supply was manifested not only in the first national Forest Act, adopted in 1903, but also in the creation of governmental authorities responsible for implementing it (Lämas and Fries, 1995). In the first half of the $20^{\text {th }}$ century, continuous cover forestry was tried in Sweden according to German practice, yet regeneration was less successful in Sweden than in Germany (due to climate and soil conditions) and the method was subsequently named “Green Lies.” Instead clear felling and planting was identified as the best way forward in Sweden. The strategy resulted in a substantial increase in the Swedish forest volume during the 20th century, of great benefit to the national economy (Ekelund and Hamilton, 2001).

In addition, during the same period, private landowners formed forest owners' associations aiming to balance the financial power of large industrial companies. Acting as producer cooperatives, the associations became important players in timber price negotiations and also primary forest management advisors for their members and key promoters of the “high-production” paradigm (Brukas and Sallnäs, 2012).

However, during the last part of the $20^{\text {th }}$ century, concern about the loss of biodiversity resulted in a general increase in the demand for forest conservation in order to prevent local extinction of species and degradation of species composition. For instance, the Swedish Forest Act from 1993 (currently in effect) establishes that production targets and environmental objectives should be of equal importance. As stated in the first paragraph of the Forest Act of 1993, “The forest is a national and renewable resource. It shall be managed in such a way as to provide a valuable yield and at the same time preserve biodiversity.” This is to say that preservation of natural and environmental values should be prioritized to the same extent as forest production values.

The ecosystem services provided by the forest landscapes depend on the composition of tree species (monoculture or mixed forests), the management, and the logging practices. For 
instance, forests managed to maximize productivity of biomass (timber, pulpwood, and bioenergy) are often monocultures of Norway spruce or Scots pine, with the common management practice of similar age and clear felling. ${ }^{3}$ However, such monocultures have low biodiversity. An alternative would be to have a more heterogeneous forest landscape, with a mix of different tree species and uneven ages. Yet, such a forest landscape creates trade-offs between forest productivity and biodiversity. ${ }^{4}$ These trade-offs between a highly productive private forest and other ecosystem services, and in particular biodiversity, make it unlikely to achieve the two objectives stated by the Swedish Forest Act in the absence of further incentives to compensate forest owners for the potential productivity losses. ${ }^{5}$ Insights on forest values among different stakeholders are crucial in order to understand the opportunity costs of biodiversity conservation to private forest owners as well as the potential for creation of markets for compensation.

\section{The Survey}

The surveys, including the choice experiment (CE), were developed in close cooperation with both social and natural scientists and different forest experts. Focus groups and survey pretests using online surveys were conducted with both citizens and forest owners. The final survey contained background information about Swedish forests, a description of the attributes and the levels, six sets of binary choice questions, and a questionnaire.

\footnotetext{
${ }^{3}$ Even though Norway spruce and Scots pine are the most commonly planted tree species (Scots pine is also commonly regenerated by seed), other species are planted if the main purpose is to produce bioenergy - although the tops and branches of spruce and pine are also frequently harvested to produce bioenergy.

${ }^{4}$ This type of forest landscape also produces other ecosystem services such as storm and pest protection (Christiansen and Bakke, 1988), recreational values and water flows. However, these are out of the scope of this study.

${ }^{5}$ In Sweden there are currently both public and private forest protection compensations. However, they are not directly intended to protect biodiversity in the same way as defined in our paper. For instance, there are two forms of government programs (e.g., natural conservation and habitat protection agreements) compensating forest owners for voluntary refraining from harvesting areas of particular environmental interest. Further, the Forest Stewardship Council (FSC) and the Programme for the Endorsement of Forest Certification (PEFC) offer around 1.1-2.1 EUR per $\mathrm{m}^{3}$ of forest products conditional on several criteria, e.g., that at least $5 \%$ of the productive forest area is set aside for biodiversity conservation and that an extended consideration of biodiversity and social aspects in managed areas are taken (SÖDRA, 2014).
} 
In all questionnaires, the $\mathrm{CE}$ was presented as the first part. The questionnaire to citizens then continued with a set of questions about their relationship with the forest and some socioeconomic questions. The forest owners were given a similar but slightly longer questionnaire that in addition included questions regarding their own forest property. The forest officials' questionnaire included specific questions regarding their role as forest officials.

In the CE, the respondents faced six choice sets, each with two different response alternatives. Each alternative had six attributes. The attributes and levels are summarized in Table 1. We use age and structure of the forest as well as tree species composition as management outcomes. We use forest birds as an indicator of biodiversity in the production forest, as it has been shown to be a good indicator of biodiversity (Bibby, 1999). It is also an indicator used in policies regarding biodiversity in Sweden. ${ }^{6}$

Since most forest in Sweden is privately owned, we let the market price of one of the main products from forest production reflect the increased cost of management. Thus, the cost attribute was expressed as an increase in household expenditures on paper products. ${ }^{7}$ We started from the average consumption of paper products of $315 \mathrm{EUR}^{8}$ per year for a twoperson household to create the cost attribute levels. ${ }^{9}$

As pointed out by Christie et al. (2006), valuation of biodiversity using direct elicitation of people's preferences requires the use of appropriate language to convey the meaning of biodiversity to the respondents. This can be quite a challenge, since biodiversity is a concept with complex underlying ecological ideas. In our CE, three different dimensions of biodiversity are valued: total number of forest bird species (as a proxy for species diversity), number of rare forest bird species (as a proxy for the number of species that are unique to

\footnotetext{
${ }^{6}$ Other indicators are dead wood, old forest, and fraction of broadleaved trees.

${ }^{7}$ The main reason for using paper is that large changes in the management of private forests would imply (at least in the short run), ceteris paribus, higher costs and lower revenues, which in turn ultimately would lead to higher consumer prices for goods such as toilet paper, packaging, diapers, sanitary napkins, and other paper products.

${ }^{8}$ In the survey, we used the local currency, SEK. The exchange rate was 9.5 SEK /EUR in January 2015.

${ }^{9}$ Calculations are based on data from Statistics Sweden 2014, http://www.scb.se/en /.
} 
forest ecosystems with very high biodiversity), and geographical spread of biodiversity (as a proxy for the diversity of natural habitats in the managed parts of the forest). Pictures were used to help respondents visualize the outcome of each alternative. Figure 1 shows an example of a choice set given to the citizens.

Figure 1. Choice set example.

If you could only choose between these two representative production forest areas in Sweden, which area would you prefer given the costs involved? Please mark your choice for the alternative that you prefer.

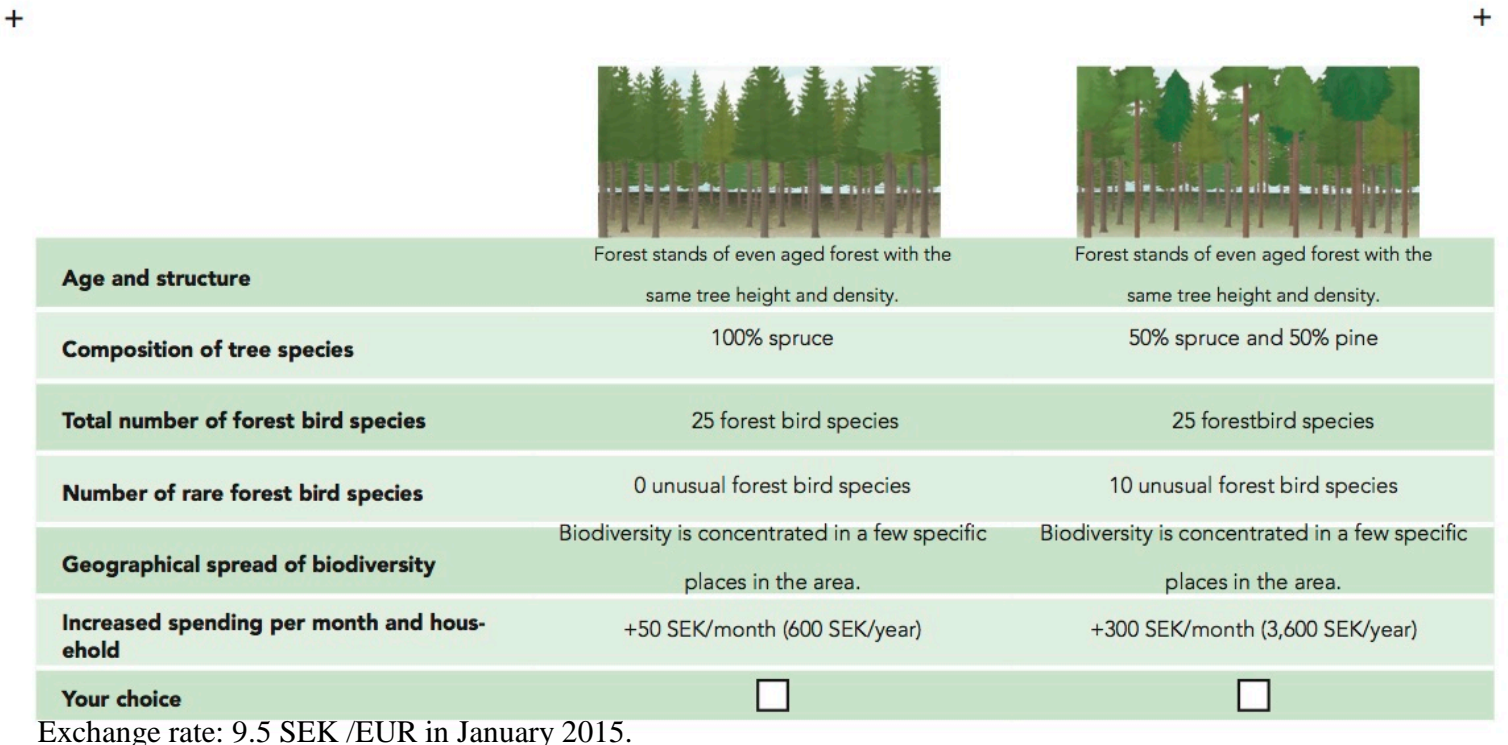

In an effort to keep the number of attributes and the experimental design manageable, we did not include characteristics of productive forest that are not directly important to the research questions. Instead we kept these attributes fixed for all choice sets and informed the respondents of this in the survey instructions. The first attribute that was held constant is size. Forest managers and ornithologists emphasized that a 100 hectare forest includes a great deal of biodiversity represented in a potential high number of forest bird species.

The second fixed attribute is recreation. This is an important consideration when respondents think about the value of forests yet has already been studied extensively (e.g., the recent studies by Campbell et al., 2014 and Ovaskainen et al., 2012). The third fixed attribute 
is distance to home. Proximity to environmental amenities has been found to increase willingness to pay (WTP) (see, e.g., Costanza et al., 2007). We therefore set the distance to a 30-minute drive from the respondent's home or, in the case of the forest officials, from the respondent's work.

The CE was almost identical for the three respondent groups, with the exception that the forest officials were asked to make their choices based on their recommendation as professionals and not as individuals. Thus, we are not interested in their private preferences, even if this could of course influence their choice.

To create the choice sets, we followed standard practice in the choice modeling literature (Adamowicz et al., 1997; Adamowicz et al., 1998; Louviere et al., 2000). We created 36 choice sets using a D-0 design (efficient with coefficient priors equal to zero) in Ngene (Vermeulen et al., 2008; Kuhfeld, 2010). The D-0 design was used to create exactly the same design for the three respondent groups. We could have used the coefficient values for the overall sample as priors, but as forest owners and citizens were found to have differences in their preferences (different coefficient values) in the pre-study, we decided to keep coefficient priors at zero.

We created a block design where the 36 choice sets were separated into blocks of six choice profiles, yielding six unique surveys with six choice questions each. In order to account for possible ordering effects, we reversed the order of the questions in half the surveys and obtained 12 unique versions of the survey. Moreover, to reduce the hypothetical bias, a cheap-talk script was included (Carlsson et al., 2005: List et al., 2006). 
Table 1. Attributes and levels in the choice experiment.

\begin{tabular}{|c|c|c|}
\hline Attribute & Description to respondents & Levels \\
\hline Age and structure & $\begin{array}{l}\text { In a forest where clear felling is used, the forest is harvested every } 60-100 \text { years, resulting in a } \\
\text { forest divided in stands with the same age and height of the trees within each stand. In a non- } \\
\text { clear felling forestry (i.e., continuous forestry), some selected trees in the forest are harvested } \\
\text { every 15-30 years, giving a different-aged forest with varying tree height. }\end{array}$ & $\begin{array}{l}\text { Forest stands of even-aged forest with the } \\
\text { same tree height and density. } \\
\text { Different-aged forest with different tree } \\
\text { heights and density. }\end{array}$ \\
\hline Composition of tree species & $\begin{array}{l}\text { The most common tree species in Sweden are spruce, pine, and birch. The composition of the } \\
\text { various tree species in a production forest affects its resistance to various disturbances such as } \\
\text { storms and insect damage, which can lead to lost revenue from the forest. A production forest } \\
\text { consisting of only one species can have greater difficulty resisting such interference, } \\
\text { compared with a forest composed of several tree species. A more mixed composition of tree } \\
\text { species and ages, however, implies more costly forest management. }\end{array}$ & $\begin{array}{l}100 \% \text { spruce } \\
50 \% \text { spruce and } 50 \% \text { pine } \\
33 \% \text { spruce, } 33 \% \text { pine, and } 33 \% \text { hardwood }\end{array}$ \\
\hline $\begin{array}{l}\text { Total number of forest bird } \\
\text { species }\end{array}$ & \multirow{2}{*}{$\begin{array}{l}\text { Biodiversity in production forests can be measured in the number of species of plants, } \\
\text { animals, and fungi. Since it is difficult to measure all of these species, forest birds, birds that } \\
\text { are heavily dependent on forest appearance and composition for their survival, are used as an } \\
\text { indicator of biodiversity in the Swedish production forest landscape. Biodiversity can be } \\
\text { stated as the total number of forest bird species in a production forest area, or as the number of } \\
\text { rare forest bird species which indicates the number of species found only in production forest } \\
\text { areas with higher biological quality. }\end{array}$} & $\begin{array}{l}15 \text { forest species } \\
25 \text { forest species } \\
40 \text { forest species }\end{array}$ \\
\hline $\begin{array}{l}\text { Number of rare forest bird } \\
\text { species }\end{array}$ & & $\begin{array}{l}0 \text { unusual forest species } \\
5 \text { unusual forest species } \\
10 \text { unusual forest species }\end{array}$ \\
\hline $\begin{array}{l}\text { Geographical spread of } \\
\text { biodiversity }\end{array}$ & $\begin{array}{l}\text { In a production forest area, biodiversity can be either concentrated in a few specific places or } \\
\text { scattered throughout the area as described in the maps below. Each black dot represents a } \\
\text { smaller area of production forest area where biodiversity is high. }\end{array}$ & $\begin{array}{l}\text { Biodiversity is concentrated in a few } \\
\text { specific places in the area. } \\
\text { Biodiversity is scattered throughout the } \\
\text { area. }\end{array}$ \\
\hline $\begin{array}{l}\text { Cost - Increased spending per } \\
\text { month and household }\end{array}$ & $\begin{array}{l}\text { Achieving certain properties in a production forest area requires different management } \\
\text { measures. Considerably changing the current way of managing forest will imply higher costs } \\
\text { and less revenue, which will ultimately lead to higher consumer prices for goods such as toilet } \\
\text { paper, packaging, diapers, sanitary napkins, and other paper products. }\end{array}$ & $\begin{array}{l}\text { +5.3 EUR/month (63.2 EUR/year) } \\
\text { +10.5 EUR/month (126.3 EUR/year) } \\
\text { +17.4 EUR/month (208.4 EUR/year) } \\
\text { +24.2 EUR/month (290.5 EUR/year) } \\
\text { +31.6 EUR/month (379 EUR/year) } \\
\text { +36.8 EUR/month (442.1 EUR/year) }\end{array}$ \\
\hline
\end{tabular}




\section{Theoretical Framework and Model Specification}

We base the analysis of the choice experiment on a standard random utility approach in which discrete choices are described in a utility maximization framework (McFadden, 1974; Manski, 1977). In this model, the utility of an individual's choice consists of one observable deterministic component and one unobservable stochastic component. The utility for individual $q$ choosing alternative $i$ can be expressed as:

$$
U_{i q}=\boldsymbol{x}_{i}^{\prime} \boldsymbol{\beta}+\varepsilon_{i q},
$$

where $\boldsymbol{x}_{\boldsymbol{i}}^{\prime}$ is a vector of the attributes describing alternative $i$, namely forest age and structure, composition of tree species, total number of forest bird species, number of rare forest bird species, geographical spread of biodiversity, and cost. The focus of our estimation is $\boldsymbol{\beta}$, the

vector of parameters for the attributes. $\varepsilon_{i q}$ is the stochastic term representing the unobservable part of the utility. Individual $q$ chooses alternative $i$ over alternative $j$ if $U_{i q}>U_{j q}$.

The parameters are estimated using a random parameter logit model in Nlogit 5.0 where the panel properties, i.e., that the same respondent is making repeated choices, are taken into account (Train, 2009; McFadden and Train, 2000). This model allows for unobservable heterogeneity. We assume that all parameters other than the cost parameter are normally distributed. To estimate the parameters, we rely on simulation methods as the unconditional probability that an individual chooses a particular alternative in a choice set is given by the integrals of the standard logit probabilities over all possible values of $\beta$ (for details see Train, 2009). The model is estimated using 500 Halton draws.

In the present paper the focus is on investigating different stakeholders' preferences for alternative forest management practices with different biodiversity outcomes and, further, which dimensions of biodiversity are valued the highest and whether these dimensions are valued the same across stakeholders. We estimate the model in equation (1) separately for each sample, and from comparisons between samples we obtain the marginal WTP for the 
attributes by taking the ratio between the attribute parameters and the cost parameter. Note that the WTPs obtained for the forest officials are not their private WTPs; instead they should be interpreted as their professional preference for the attributes.

To ensure that any differences found in preferences between stakeholders are not due to differences in socio-economic characteristics, we control for the characteristics we have for all samples. Further, to explain potential differences within each sample, we also estimate models for a series of observable characteristics that are specific for each sample. The characteristics are detailed in Table 2.

Table 2. Observable socio-economic characteristics.

\begin{tabular}{|c|c|c|c|c|c|}
\hline Variable & Description & $\begin{array}{c}\text { All } \\
\text { samples }\end{array}$ & Citizens & $\begin{array}{l}\text { Forest } \\
\text { owners }\end{array}$ & $\begin{array}{c}\text { Forest } \\
\text { officials }\end{array}$ \\
\hline Gender & Dummy for male. & $\mathrm{X}$ & & & \\
\hline Age & In years. & $\mathrm{X}$ & & & \\
\hline Education & Dummy for university education & $\mathrm{X}$ & & & \\
\hline Urban area & $\begin{array}{l}\text { Dummy for living in a city with more } \\
\text { than } 20,000 \text { inhabitants. }\end{array}$ & $\mathrm{X}$ & & & \\
\hline Occupation & $\begin{array}{l}\text { Dummy for employed (including self- } \\
\text { employed) }{ }^{(1)} \text {. }\end{array}$ & & $\mathrm{X}$ & $\mathrm{X}$ & \\
\hline Household income & Monthly net income in 100 EUR. & & $\mathrm{X}$ & $\mathrm{X}$ & \\
\hline $\begin{array}{l}\text { Distance to closest } \\
\text { forest }\end{array}$ & Kilometers from home & & $\mathrm{X}$ & & \\
\hline $\begin{array}{l}\text { Familiarity with } \\
\text { forest }\end{array}$ & $\begin{array}{l}\text { Dummy if one or more visits per } \\
\text { month. }\end{array}$ & & $\bar{X}$ & & \\
\hline Forest size & $\begin{array}{l}\text { Dummy for forest property larger than } \\
200 \text { ha. }\end{array}$ & & & $\mathrm{X}$ & \\
\hline $\begin{array}{l}\text { Forest owners' } \\
\text { association }\end{array}$ & $\begin{array}{l}\text { Dummy for membership in a forest } \\
\text { owners' association. }\end{array}$ & & & $\mathrm{X}$ & \\
\hline Resident & $\begin{array}{l}\text { Dummy for those who live in the } \\
\text { municipality where their forestry } \\
\text { property is located. }\end{array}$ & & & $\mathrm{X}$ & \\
\hline Inheritance & Dummy for inherited forest property. & & & $\mathrm{X}$ & \\
\hline $\begin{array}{l}\text { Main decision } \\
\text { maker }\end{array}$ & $\begin{array}{l}\text { Dummy for main decision maker of the } \\
\text { forest management, used as a proxy for } \\
\text { self-employed work on their holdings. }\end{array}$ & & & $\bar{X}$ & \\
\hline $\begin{array}{l}\text { Forest related } \\
\text { education }\end{array}$ & Dummy for forest related education. & & & & $\mathrm{X}$ \\
\hline $\begin{array}{l}\text { Public forest } \\
\text { officials }\end{array}$ & $\begin{array}{l}\text { Dummy for officials with a public } \\
\text { policy role. }{ }^{(2)}\end{array}$ & & & & $\mathrm{X}$ \\
\hline
\end{tabular}

(1) Not employed or self-employed are, e.g., retired, self-employed, student, unemployed, or on maternity leave. All forest owners are registered private operators; hence some income could still be coming from the forest property.

(2) Officials at the Swedish Forest Agency in contrast to private officials at a forestry company or a forest owners' association. 
We estimate models including interaction terms between socio-economic variables and the attributes, specified as

$$
U_{i q}=\boldsymbol{x}_{\boldsymbol{i}}^{\prime} \boldsymbol{\beta}+\left(\boldsymbol{x}_{\boldsymbol{i}}^{\prime} \mathbf{z}_{\boldsymbol{q}}\right)^{\prime} \boldsymbol{\delta}+\varepsilon_{i q},
$$

where in addition to equation (1), $\left(\boldsymbol{x}_{\boldsymbol{i}}^{\prime} \mathbf{z}_{\boldsymbol{q}}\right)$ is a vector of interaction terms between the attributes and socio-economic variables, and $\delta$ captures the heterogeneity in preferences for the attributes that is due to individual characteristics. When controlling for observable socioeconomic characteristics between the samples, the parameters in equation (2) are estimated using random parameter logit models. However, when we explore the observable characteristics within samples, we end up with a large amount of interactions and the random parameter model tends to not converge. Hence, we estimate the parameters in equation (2) using multinomial logit models ${ }^{10}$, which apply maximum likelihood estimation.

\section{Data}

The data was gathered in the spring of 2014. For the citizens, we use survey responses from a questionnaire sent out by mail, with an option to respond online, in March 2014 to a random sample of 4,000 men and women aged 18-84, selected from the Swedish census registry (SPAR), which includes all persons who are registered as Swedish residents. In total, 1,215 individuals returned the questionnaire, of which 1,104 were available for analysis since respondents who had not answered any of the choice questions were dropped. ${ }^{11}$

For the forest owners, we use survey responses from a questionnaire sent out by mail, with an option to respond online, in March 2014 to a random sample of 6,000 individuals. We used

\footnotetext{
${ }^{10}$ Another reason for using the multinomial logit model is that any relevant interactions in this model should also turn up in the random parameter logit, and if not, the random parameter logit model does a poor job of uncovering relevant interacting factors.

${ }^{11}$ The response rate is $30 \%$, corrected for those who had not received the questionnaire due to returned mail. Seventy-eight percent answered on paper, the rest online.
} 
two sampling frames. The first consisted of forest owners who participated in courses, counseling, and information meetings organized by the Swedish Forest Agency. The second consisted of forest owners registered by the Swedish Land Survey (Lantmäteriet) and the Swedish Forest Agency. The selection was random and consisted of 3,000 individuals from each sampling frame. In total, 2,627 forest owners returned the questionnaire, of which 2,398 were available for analysis. $^{12}$

For the citizens and the forest owners, the collection consisted of four rounds. The first round consisted of a notification postcard informing about the upcoming survey. A link and a personal code were provided in the postcard for those who wished to complete the survey online. The second round consisted of the survey including an information letter and a return envelope with postage paid. The third round was a reminder and the fourth a resending of the survey.

For the forest officials, we use survey responses from an online questionnaire sent out in May 2014 to a census of 1,139 recipients. The census consisted of forest officials in a register we compiled by searching the internet for contact information for forest officials at different levels all over Sweden, including governmental agencies, forest companies, and forest owners' associations. The participants received an e-mail with an invitation to take part in the online survey. In total, 544 forest officials returned the questionnaire, of which 387 were available for analysis. ${ }^{13}$

Table 3 presents some descriptive statistics of the samples of citizens, forest owners, and forest officials (both for the whole sample and for public and private officials separately). We find that most of the samples differ significantly from each other when it comes to distribution

\footnotetext{
${ }^{12}$ The response rate is $44 \%$, corrected for those who had not received the questionnaire due to returned mail. Eighty-six percent responded on paper, the rest online.

${ }_{13}$ The response rate is $53 \%$, corrected for those who had not received the questionnaire due to the email bouncing. The large difference between the number of received questionnaires and the number of questionnaires available for the choice experiment analysis is due to the fact that the former include respondents with incomplete responses, i.e., non-response to the choice experiment part, rendering their questionnaires ineligible for analysis.
} 
of gender, age, education, and living in a metropolitan area. The forest sector in Sweden is generally male dominated where most owners and officials live outside the metropolitan areas. Forest owners are generally older than other stakeholders and public forest officials are generally older than private officials. Forest officials on average have more education compared with the other stakeholders, and public officials have the highest rate of university education.

Comparisons between the citizen and forest owner samples with the respective national populations are found in Appendix Table A1. ${ }^{14}$ In general, both samples are fairly representative of the populations. However, compared with the population at large, the citizen sample is slightly older and has more education and higher disposable income, and the individuals in this sample are also less likely to live in a metropolitan area. This is not surprising as the questionnaire is focused on forest and the interest in forest-related issues may be higher among people living closer to forested areas.

There are almost 330,000 non-industrial private forest owners in Sweden. Comparing our sample with the national population of forest owners, we find an under-representation of females and younger forest owners in the sample. We also find an over-representation of larger forest owners, members of a forest owners' association, and forest owners living in the municipality where their forestry property is located, all of which may imply a larger degree of engagement in forest activities.

These differences mean that some precaution needs to be taken when drawing general conclusion regarding the populations.

\footnotetext{
${ }^{14}$ Descriptive statistics for the population of forest officials are not presented as the total population was selected to receive the survey and there is no data on individual characteristics available for those who did not answer the survey.
} 
Table 3. Descriptive statistics of the samples of citizens, forest owners and forest officials.

\begin{tabular}{|c|c|c|c|c|c|c|c|c|c|c|}
\hline & $\begin{array}{l}\text { Sample of } \\
\text { citizens } \\
(1)\end{array}$ & $\begin{array}{c}\text { Sample of } \\
\text { forest owners } \\
\text { (2) }\end{array}$ & \begin{tabular}{|c|} 
Sample of \\
forest officials \\
(3) \\
\end{tabular} & $\begin{array}{c}\text { Sample of public } \\
\text { forest officials } \\
\text { (4) }\end{array}$ & \begin{tabular}{|c|}
$\begin{array}{c}\text { Sample of private } \\
\text { forest officials } \\
\text { (5) }\end{array}$ \\
\end{tabular} & $\begin{array}{c}P \text {-values } \\
H_{0}: 1=2 \\
\end{array}$ & $\begin{array}{c}P \text {-values } \\
H_{0}: 2=3\end{array}$ & $\begin{array}{c}P \text {-values } \\
H_{0}: 4=5\end{array}$ & $\begin{array}{c}P \text {-values } \\
H_{0}: 2=4\end{array}$ & $\begin{array}{l}P \text {-value } \\
H_{0}: 2=5\end{array}$ \\
\hline $\begin{array}{l}\text { Gender } \\
\text { Male } \\
\text { Female } \\
\text { Age } \\
\text { 18-30 years } \\
31-45 \text { years } \\
\text { 46-60 years } \\
61-75 \text { years } \\
\text { 75-84 years } \\
\text { Metropolitan location } \\
\text { Stockholm, Gothenburg and Malmö } \\
\text { Other } \\
\text { Education } \\
\text { Completed } 9 \text { years } \\
\text { Completed } 12 \text { years } \\
\text { University education } \\
\text { Type of education } \\
\text { Forest related } \\
\text { Non-forest related } \\
\text { Income (EUR) } \\
\text { Average disposable income per month } \\
\text { Type of forest official } \\
\text { Public } \\
\text { Private } \\
\text { Large forest owners }>200 \text { ha } \\
\text { Yes } \\
\text { No } \\
\text { Resident forest owner }{ }^{b} \\
\text { Yes } \\
\text { No } \\
\text { Member of a forest owners' association } \\
\text { Yes } \\
\text { No }\end{array}$ & $\begin{array}{l}47 \% \\
53 \% \\
13 \% \\
19 \% \\
25 \% \\
32 \% \\
11 \% \\
\\
26 \% \\
74 \% \\
\\
19 \% \\
36 \% \\
45 \%\end{array}$ & $\begin{array}{c}79 \% \\
21 \% \\
1 \% \\
8 \% \\
26 \% \\
52 \% \\
13 \% \\
7 \% \\
93 \% \\
23 \% \\
34 \% \\
43 \% \\
\\
\\
\\
\\
\\
\\
\\
\\
\\
142 \mathrm{EUR} \\
\\
\\
\\
\\
13 \% \\
87 \% \\
73 \% \\
27 \% \\
52 \% \\
48 \% \\
\end{array}$ & $\begin{array}{c}90 \% \\
10 \% \\
\\
8 \% \\
35 \% \\
44 \% \\
13 \% \\
- \\
\\
3 \% \\
97 \% \\
\\
1 \% \\
8 \% \\
91 \% \\
\\
87 \% \\
13 \% \\
\end{array}$ & $\begin{array}{c}80 \% \\
20 \% \\
\\
5 \% \\
27 \% \\
46 \% \\
23 \% \\
- \\
\\
1 \% \\
99 \% \\
\\
2 \% \\
2 \% \\
95 \% \\
\\
87 \% \\
13 \%\end{array}$ & $\begin{array}{c}95 \% \\
5 \% \\
\\
10 \% \\
39 \% \\
43 \% \\
8 \% \\
- \\
\\
3 \% \\
97 \% \\
\\
1 \% \\
11 \% \\
88 \% \\
\\
87 \% \\
13 \%\end{array}$ & 0.04 & $\begin{array}{l}<0.01 \\
<0.01 \\
<0.01\end{array}$ & $\begin{array}{l}0.01 \\
0.93\end{array}$ & $\begin{array}{l}0.02 \\
<0.01\end{array}$ & $\begin{array}{l}<0.01 \\
0.06 \\
<0.01\end{array}$ \\
\hline No. of observations ${ }^{c}$ & 1096 & 2398 & 387 & 109 & 242 & & & & & \\
\hline
\end{tabular}

Notes: ${ }^{a}$ The average income for the sample is generated from categorical data where the mean of each category is used. ${ }^{b}$ Resident forest owners are those who live in the municipality where their

forestry property is located. ${ }^{c}$ There is some variation in number of observations due to missing values in some variables for the samples. ${ }^{d}$ From Chi2 test and an unpaired t-test for income. 


\section{Results}

In this section we describe the results of the CE and robustness checks.

\subsection{Results of the Choice Experiments}

Three separate models were estimated, one for each respondent group. ${ }^{15}$ Table 4 reports the results of the random parameter logit models, which take into account the unbalanced structure of the panel as not all respondents answered all six choice sets.

In line with previous studies, we find that the preferences of forest owners and forest officials are closer to each other than those of citizens. In contrast, the citizens' preferences are different, especially those related to forest age and structure and geographical spread of biodiversity. Both forest owners and forest officials have negative preferences for these attributes while citizens have a positive preference.

Table 4 also reports the coefficients of the standard deviations from the mean coefficients, which indicate the degree of unobserved heterogeneity. The coefficients of the standard deviation of the parameters are highly significant for all samples; hence, there is considerable heterogeneity in their preferences, even up to the point that there is a considerable probability of sign reversal. However, there does not seem to be any systematic difference between the groups in the pattern of the heterogeneity.

Considering that the forest officials work with forest and have better knowledge than the citizens about the impact of different management models, one might expect their preferences to be less heterogeneous. Yet this is not the case.

\footnotetext{
${ }^{15}$ To test for order effects, separate multinomial logit models for block 1-6 and block 7-12 for each group are used. The likelihood ratio test leads to $\lambda_{\text {citizens }}=7.32, \lambda_{\text {owners }}=7.32, \lambda_{\text {officials }}=7.78$. These values are smaller than 12.59 , the critical value of the $\chi 2$ distribution at the $5 \%$ significance level with 6 degrees of freedom. Hence, the hypothesis of equal parameters could not be rejected. In other words, there is no order effect in any of the respondent groups.
} 
Table 4. Estimated Random Parameter Logit Models, standard errors in parentheses.

\begin{tabular}{|c|c|c|c|c|c|}
\hline Parameters & Citizens (1) & Forest owners (2) & Forest officials (3) & Public forest officials (4) & Private forest officials (5) \\
\hline Age and structure & $0.344 * * *(0.067)$ & $-0.534 * * *(0.062)$ & $-1.288 * * *(0.138)$ & $-0.614 * * *(0.227)$ & $-1.472 * * *(0.170)$ \\
\hline Composition of tree species & $1.140 * * *(0.071)$ & $1.432 * * *(0.062)$ & $0.773 * * *(0.094)$ & $1.333^{* * *}(0.232)$ & $0.606^{* * *}(0.102)$ \\
\hline Total number of forest bird species & $0.270 * * *(0.049)$ & $0.148 * * *(0.035)$ & $0.237 * * *(0.073)$ & $0.562 * * *(0.153)$ & $0.096(0.084)$ \\
\hline Number of rare forest bird species & $0.576^{* * *}(0.054)$ & $0.341^{* * *}(0.037)$ & $0.325^{* * *}(0.082)$ & $0.711^{* * *}(0.188)$ & $0.198 * *(0.094)$ \\
\hline Geographical spread of biodiversity & $0.244^{* * *}(0.064)$ & $-0.096 *(0.050)$ & $-0.721 * * *(0.115)$ & $-0.747 * * *(0.222)$ & $-0.723 * * *(0.141)$ \\
\hline Cost & $-0.004 * * *(<0.001)$ & $-0.005^{* * *}(<0.001)$ & $-0.004 * * *(<0.001)$ & $-0.004 * * *(0.001)$ & $-0.004 * * *(<0.001)$ \\
\hline \multicolumn{6}{|l|}{ Standard deviation } \\
\hline Age and structure & $0.985^{* * *}(0.124)$ & $1.808^{* * *}(0.099)$ & $1.236 * * *(0.197)$ & $1.286 * * *(0.365)$ & $1.158^{* * *}(0.228)$ \\
\hline Composition of tree species & $1.113^{* * *}(0.084)$ & $1.305^{* * *}(0.072)$ & $0.784 * * *(0.128)$ & $0.842^{* * *}(0.286)$ & $0.625^{* * *}(0.150)$ \\
\hline Total number of forest bird species & $0.792^{* * *}(0.069)$ & $0.775^{* * *}(0.056)$ & $0.465^{* * *}(0.128)$ & $0.453^{* *}(0.216)$ & $0.359 * *(0.169)$ \\
\hline Number of rare forest bird species & $0.776^{* * *}(0.077)$ & $0.851^{* * *}(0.061)$ & $0.753^{* * *}(0.129)$ & $0.914^{* * *}(0.256)$ & $0.651^{* * *}(0.155)$ \\
\hline Geographical spread of biodiversity & $0.741^{* * *}(0.119)$ & $1.073 * * *(0.083)$ & $0.649 * * *(0.217)$ & $0.391(0.510)$ & $0.715^{* * *}(0.221)$ \\
\hline No. of individuals & 1104 & 2398 & 387 & 109 & 242 \\
\hline No. of observations & 6493 & 14054 & 2231 & 647 & 1442 \\
\hline Log-Likelihood & -3961.3 & -8121.6 & -1255.7 & -348.0 & -798.4 \\
\hline $\mathrm{R}^{2}$ (constants only) & 0.118 & 0.166 & 0.183 & 0.221 & 0.201 \\
\hline
\end{tabular}


Figure 2. Mean willingness to pay (WTP) in EUR per month for different forest attributes and mean WTP for a high biodiversity scenario compared with business as usual for citizens and forest owners; 95\% confidence interval.
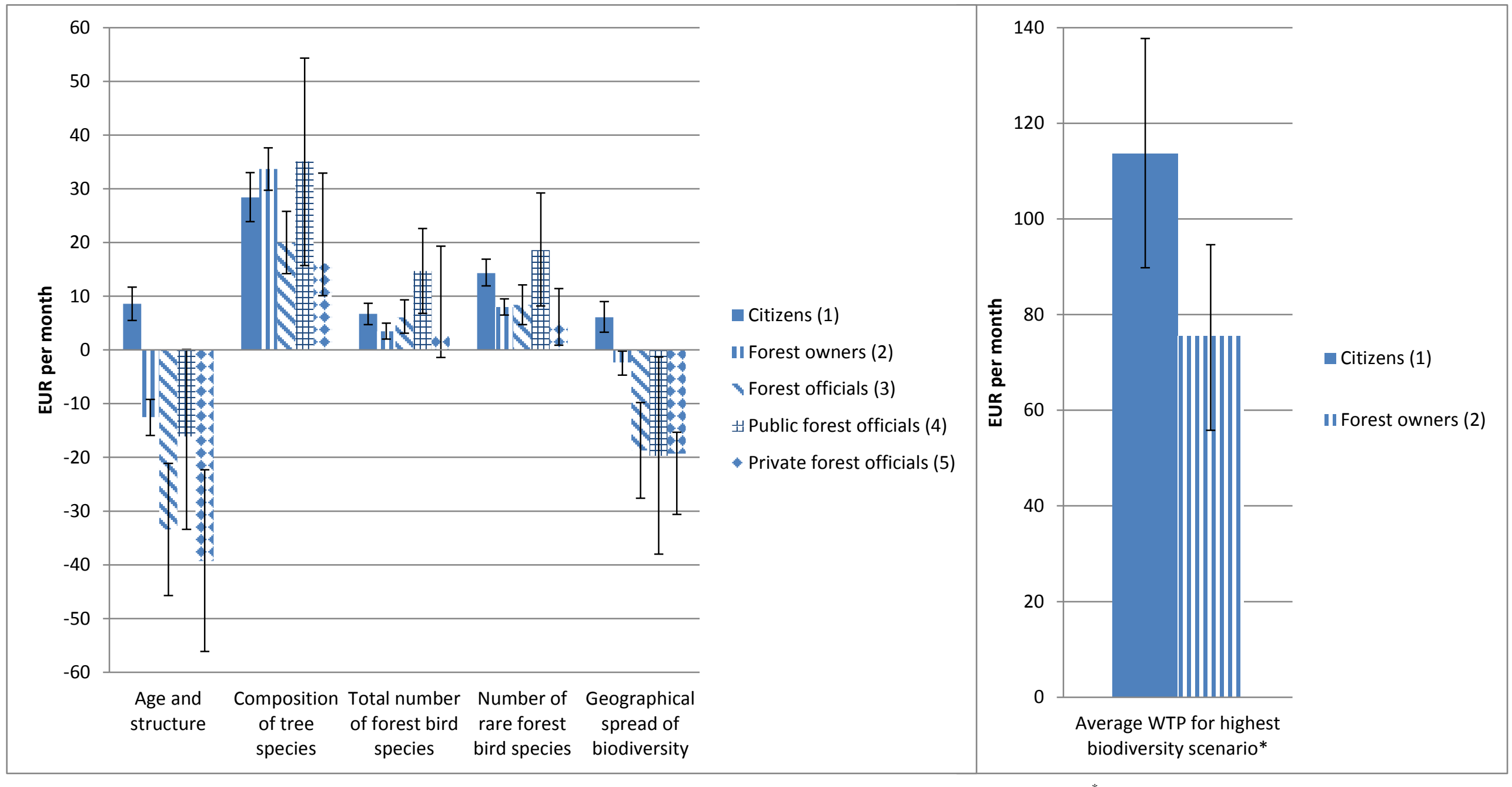

${ }^{*} H_{0}: 1=2 ;$-value $<0.01$. 
Table 5. P-values of a Bonferroni multiple comparison test ${ }^{16}$ of equal mean WTP between stakeholders.

\begin{tabular}{lccccccc}
\hline \hline & $\begin{array}{l}P \text {-values } \\
H_{0}: 1=2\end{array}$ & $\begin{array}{c}P \text {-values } \\
H_{0}: 2=3\end{array}$ & $\begin{array}{c}P \text {-values } \\
H_{0}: 4=5\end{array}$ & $\begin{array}{c}\text { P-values } \\
H_{0}: 1=4\end{array}$ & $\begin{array}{c}P \text {-value } \\
H_{0}: 1=5\end{array}$ & $\begin{array}{c}P \text {-values } \\
H_{0}: 2=4\end{array}$ & $\begin{array}{c}P \text {-value } \\
H_{0}: 2=5\end{array}$ \\
\hline Age and structure & $<0.01$ & $<0.01$ & $<0.01$ & $<0.01$ & $<0.01$ & 0.17 & $<0.01$ \\
$\begin{array}{l}\text { Composition of tree } \\
\text { species }\end{array}$ & $<0.01$ & $<0.01$ & $<0.01$ & $<0.01$ & $<0.01$ & 0.58 & $<0.01$ \\
$\begin{array}{l}\text { Total number of forest } \\
\text { bird species }\end{array}$ & $<0.01$ & $<0.01$ & $<0.01$ & $<0.01$ & $<0.01$ & $<0.01$ & 0.13 \\
$\begin{array}{l}\text { Number of rare forest } \\
\text { bird species }\end{array}$ & $<0.01$ & 0.36 & $<0.01$ & $<0.01$ & $<0.01$ & $<0.01$ & $<0.01$ \\
$\begin{array}{l}\text { Geographical spread } \\
\text { of biodiversity }\end{array}$ & $<0.01$ & $<0.01$ & 0.48 & $<0.01$ & $<0.01$ & $<0.01$ & $<0.01$ \\
\hline
\end{tabular}

Comparing: citizens (1) and forest owners (2); forest owners (2) and forest officials (3); public officials (4) and private officials (5); citizens (1) and public officials (4); citizens (1) and private officials (5); forest owners (2) and public officials (4); forest owners (2) and private officials (5).

Since the scale parameters might be different between the models, we cannot make comparisons of the relative importance of attributes between different stakeholders. We therefore estimate and compare the willingness to pay (WTP) for the various attributes for each stakeholder separately. By dividing each attribute parameter with the cost parameter, we estimate the marginal WTP. The results are presented in Figure 2 and p-values of a Bonferroni multiple comparison test of equal mean WTP are presented in Table 5. Figure 2 also includes the total WTP for the highest biodiversity scenario in our CE compared with business as usual, to highlight the room for compensation.

According to a Wald test, the marginal WTP estimates are significant at a $1 \%$ significance level for all stakeholders and for all attributes. Citizens have positive WTP for all attributes, while forest owners and forest officials have negative marginal WTP both for a more diverse forest in terms of age and structure and for geographical spread of biodiversity in the landscape. All stakeholders have the highest marginal WTP for a more mixed composition of tree species followed by an increased number of rare forest bird species. Forest owners and private forest officials rank a more diverse forest in terms of age and structure as the least important attribute (with a negative marginal WTP), while citizens rank this attribute as the

\footnotetext{
${ }^{16}$ Benjamini and Hochberg, 1995.
} 
third most important. For public forest officials, geographical spread of biodiversity in the forest landscape is the least important attribute (with a negative marginal WTP).

Interestingly, the number of rare forest bird species is the highest valued dimension of biodiversity by all stakeholders. ${ }^{17}$ This attribute was explained to participants as an indicator of the number of species found only in production forest areas with higher biological quality. For forest officials in general, however, there is no statistically significant difference between their preferences for number of rare forest bird species and total number of forest bird species. For citizens, there is no statistically significant difference in value between total number of bird species and geographical spread of biodiversity.

To extend the analysis of the differences in marginal WTP between the respondent groups, Table 5 reports the results of a Bonferroni multiple comparison test. ${ }^{18}$ Citizens have a significantly higher valuation of all attributes compared with forest owners, with one exception: forest owners generally have a higher valuation of forests with high diversity in terms of tree species. One reason for this might be that a more diversified forest in terms of tree species provides storm and pest protection (see, e.g., Christiansen and Bakke, 1988).

Comparing forest owners and forest officials, two stakeholders with close interaction, we see that forest officials generally put a lower value on forests with higher diversity in terms of age and tree species as well as on geographical spread of biodiversity. There is no significant difference between forest owners and forest officials in valuation of number of rare forest bird species. However, forest officials value total number of forest bird species higher than forest owners.

\footnotetext{
${ }^{17}$ A pairwise Wald test of equal WTP for the three dimensions of biodiversity within each sample was conducted with the following results: WTP total forest birds=WTP rare forest birds (p-value $=<0.01 ;<0.01 ; 0.36$ ); WTP total forest birds=WTP geographical spread (p-value=0.72; $<0.01 ;<0.01$ ); WTP rare forest birds=WTP geographical spread (p-value=<0.01; $<0.01$; $<0.01$ ). P-values are presented for citizens, forest owners and forest officials respectively.

${ }^{18}$ An alternative to a Bonferroni-corrected test would be the equivalence test suggested by Poe et al. (1994), where the mean equality between two random distributions are tested based on the Krinsky-Robb procedure. The advantage with the Poe et al. (1994) test is that it does not restrict the distribution to a specific form. However, since the parameters in the mixed parameter logit model are already restricted to a normal distribution, we do not expect to gain much by diverting from the Bonferronicorrected test.
} 
Looking at public and private forest officials separately, we find that public officials value all attributes higher than private officials, except for geographical spread of biodiversity where there is no significant difference between their negative valuations. Further, we find that public forest officials and forest owners have similar negative marginal WTPs for diverse forest age and structure and similar positive marginal WTPs for mixed composition of trees. Private forest officials and forest owners have similar quite low WTPs for total number of forest bird species compared with other stakeholders. In contrast, public forest officials have higher preferences for biodiversity in terms of total number of forest bird species and number of rare forest bird species than both citizens and forest owners. These results indicate that there is a clear production focus both among forest officials and forest owners, where private forest officials have the strongest market orientation.

Finally, we compare the WTP for the highest biodiversity scenario between citizens and forest owners. ${ }^{19}$ We find that citizens have a significantly higher total WTP for this scenario compared with forest owners. This indicates that on average, there is room for compensation for more biodiversity protection.

\subsection{Observable Heterogeneity in Preferences Between Samples}

One reason the results differ between the groups could be that the socio-economic characteristics are different. Forest officials are all highly educated and the sector is male dominate. Citizens are younger and live to a higher extent in metropolitan areas compared with both forest owners and officials. This should, however, not be seen as a sample selection problem per se, but could explain part of the differences in preferences.

\footnotetext{
${ }^{19}$ This is calculated by taking the sum of the marginal WTP multiplied by the highest attribute level of each attribute.
} 
To control for socio-economic characteristics, we interact the attributes with age and with whether or not the respondent is male, has a university education, and lives in a metropolitan area. The estimated results are presented in Table A2 in the Appendix. ${ }^{20}$

The results show that the differences in preferences for the different attributes do not seem to be a simple reflection of the preferences of respondents with similar characteristics. For instance, we find that older forest owners and citizens have a higher preference for a more diverse forest. ${ }^{21}$ Similarly, university education has a positive effect on preferences for a more diverse forest for both forest owners and citizens compared with those with less education. Further, living in a metropolitan area does not seem to explain variation among stakeholders. ${ }^{22}$ The only interaction where we find the sign of the interactions goes in opposite direction is for males, where male forest owners, in contrast to citizens, value biodiversity less than female forest owners.

\subsection{Observable Heterogeneity in Preferences Within Samples}

In Table 4, we find highly significant heterogeneity in preferences for the attributes in all samples. To explore this further, we add sample-specific interactions between socio-economic characteristics with all attribute parameters and estimated multinomial logit models using a backward regression approach; see estimated results in Table A3 in the Appendix. ${ }^{23}$

\footnotetext{
20 The unobservable heterogeneity in preferences is still highly significant in all samples, indicating that there is still heterogeneity in preferences that we cannot explain.

${ }^{21}$ This result is in contrast to previous studies (e.g., Nordlund and Westin, 2011; Eriksson et al., 2012). However, even though young people might care about the environment quite a bit, they might also have tighter budget constraints, implying that their preference is smoothed by the fact that they have to pay for it (compared with studies that only ask for rankings). This result might also be related to preferences for landscape characteristics during childhood (e.g., Chawla, 2007).

22 The interaction between metropolitan location and the rare forest bird species attribute is significantly positive only for forest officials, while the interaction between metropolitan location and geographical spread is significantly negatively only for forest owners, compared with those in more rural areas.

${ }^{23}$ In the first step we use a full model with all interaction parameters, but since there may be multicollinearity between variables in the full model, which may disguise interesting patterns, we instead present the estimated results of a backward regression model in Table A3, including only the parameters that are statistically significant at a $10 \%$ level. The results are fairly robust for the two models in the sense that statistically significant coefficients in the full model also to a large extent are significant in the stepwise model (exceptions in all samples are some interactions between attribute parameters and university education. For forest owners, the exception is some interactions between attribute parameters and gender). All choice attributes are modelled as linear variables.
} 
For citizens, we find that familiarity with forests (measured as one or more visits to the forest per month) positively affects the valuation of a more diverse composition of tree species, total number of forest bird species, and number of rare forest bird species. Distance to the closest forest has no effect on the attributes.

For forest owners, the size of the forest property has a positive effect on the preference for number of rare forest bird species, while it affects the preferences for a more diverse forest in terms of age, structure, and tree species composition negatively. Further, we find that members of forest owners' associations have higher disutility from a more diverse forest age and structure. Since a more diverse forest age and structure might imply potentially higher production costs, at least in the short run, one potential explanation for these results might be that large owners and members of forest owners' associations are more involved than other forest owners in management activities (Eriksson, 2012).

Moreover, we find that for forest officials, forest education positively affects the valuation of more diverse forest age, structure, and tree composition. Interestingly, there is a highly significant difference in preferences between professionals in the private and public sectors. As we have seen before, public forest officials, e.g., officials at the Swedish Forest Agency, value a diverse forest in terms of age, tree species, and biodiversity (e.g., numbers of forest bird species and rare forest bird species) higher than do officials at forestry companies.

\section{Discussion and Conclusions}

In this study, we show empirical results regarding the preferences of three key forest stakeholders in Sweden: citizens, forest officials, and non-industrial private forest owners. According to the results, we can say that there is a demand for biodiversity protection and biodiversity-promoting forest management practices: citizens have a positive valuation of all forest attributes in this study (e.g., number of total and rare forest bird species, geographical spread of biodiversity, and forest diversity in terms of age, structure, 
and tree species). Moreover, the general public's valuation of these attributes is statistically higher than that of forest owners, implying that there is room for compensation.

Further, we find significant heterogeneity in forest owners' preferences. This is not surprising as it indicates the existence of a large range of variation in the opportunity cost of biodiversity protection. However, it implies that an efficient policy design should have incentives that vary across forest owners in order to promote participation by those whose forests have a higher biological value.

One challenge in studies like this is to describe biodiversity to the public in an understandable way, since without such understanding the willingness to pay will be less informative. Our results indicate that citizens value different dimensions of biodiversity, confirming the view that studies that do not consider biodiversity in a broad sense fail to provide a more complete perspective of the value of biodiversity.

There is an ongoing debate regarding the benefits of land sparing (i.e., that biodiversity protection is geographically concentrated and separated from productive land activities) and land sharing (i.e., that biodiversity protection is geographically spread and integrated with productive land activities) (e.g., Fischer et al., 2014). To ensure geographical spread of biodiversity, policy makers would have to develop schemes where forest owners work in collaboration with each other and with local, regional, and national agencies. Our results show that such collaboration might be difficult to reach without further incentives as both forest owners and forest officials have negative preferences for geographical spread of biodiversity, due to potential productivity losses. To our knowledge, our study is the first to explore stakeholders' preferences for land sharing vs. land sparing. Increased understanding in this regard can potentially broaden the perspectives of the benefits from these different approaches to biodiversity protection.

Forest with high diversity in terms of tree species is highly valued by both forest owners and forest officials. One reason for this might be that a more diverse forest in terms of tree species provides storm and pest protection. Even though such preference could be driven by production goals there are positive spillovers to forest biodiversity. 
Interestingly, our results indicate that both forest owners and forest officials have a strong orientation towards production, with higher valuations of the common management practice of similar age and clear felling compared with the general public. Since the first half of the $20^{\text {th }}$ century, continuous cover forestry has been seen as something that should be avoided and clear felling and planting has instead been decided to be the best way forward in Sweden.

Even though production and environmental goals should be regarded as equally important according to the Swedish Forestry Act, we find that forest officials prefer management practices that promote production rather than biodiversity protection. The fact that this bias in preferences is particularly evident for private forest officials might lead to a continuous focus on production rather than biodiversity protection as forest owners have been shown to have more contact with private than public officials.

Although public officials have higher preferences for biodiversity compared with their private counterparts, they also tend to prefer management practices that promote production. This conflict may have negative consequences for biodiversity protection, as public forest officials work directly with regulations and guidelines to impact how forest management is carried out in practice.

Acknowledgement: This study is part of the Biodiversa research project CONNECT, funded by FORMAS. We also acknowledge the financial support from the research program Biodiversity and Ecosystem Services in a Changing Climate (BECC) at the University of Gothenburg and Lund University, as well as from Mistra-SWECIA. We are grateful for useful comments from Mitesh Kataria, Elina Lampi, Fredrik Carlsson, Mark Koetse, Gregor Vulturius, Mats Andersson, Åke Lindström, and Martin Green. 


\section{References}

Adamowicz, W., P. Boxall, M. Williams, and J. Louviere. 1998. Stated Preference Approaches for Measuring Passive Use Values: Choice Experiments and Contingent Valuation. American Journal of Agricultural Economics 80:64-75.

Adamowicz, W., J. Swait, P. Boxall, J. Louviere and M. Williams. 1997. Perceptions Versus Objective Measures of Environmental Quality in Combined Revealed and Stated Preference Models of Environmental Valuation. Journal of Environmental Economics and Management 32:65-84.

Benjamini, Y. and Y. Hochberg. 1995. Controlling the false discovery rate: a practical and powerful approach to multiple testing. Journal of the Royal Statistical Society. Series B (Methodological), 289-300.

Bibby, C.J. 1999. Making the most of birds as environmental indicators. Ostrich: Journal of African Ornithology 70(1): 81-88.

Brukas, V. and O. Sallnäs. 2012 Forest management plan as a policy instrument: stick, carrot or sermon? Land Use Policy. 29: 605-613.

Campbell, D., S. E. Vedel, B. J. Thorsen and J. B. Jacobsen. 2014. Heterogeneity in the WTP for recreational access: distributional aspects. Journal of Environmental Planning and Management 57(8): 1200-1219.

Carlsson, F., P, Frykblom and C.J. Lagerkvist. 2005. Using cheap-talk as a test of validity in choice experiments. Economics Letters 89: 147-52.

Carlsson, F., M. Kataria and E. Lampi. 2011. Do EPA administrators recommend environmental policies that citizens want?. Land Economics 87(1): 60-74.

Chawla, L. 2007. Childhood experiences associated with care for the natural world: A theoretical framework for empirical results. Children, Youth and Environments, 17(4): 144-170.

Christiansen, E. and A. Bakke. 1988. The spruce bark beetle of Eurasia. In Dynamics of forest insect populations (pp. 479-503). Springer US.

Christie, M., N. Hanley, J. Warren, K. Murphy, R. Wright and T. Hyde. 2006. Valuing the diversity of biodiversity. Ecological Economics 58: 304-317.

Costanza R, M. Wilson, A. Troy, A. Voinov, S. Liu and J. D’Agostino. 2007. The value of New Jersey's ecosystem services and natural capital. Project report to the New Jersey Department of Environmental Protection, USA.

Ekelund, H. and G. Hamilton. 2001. Skogspolitisk historia. Skogsstyrelsen Rapport 8A. Jönköping, Sweden. 
Eriksson, L. 2012. Exploring Underpinnings of Forest Conflicts: A Study of Forest Values and Beliefs in the General Public and Among Private Forest Owners in Sweden. Society \& Natural Resources: An International Journal 25(11):1102-1117.

Eriksson, L., A. Nordlund, O. Olsson and K. Westin. 2012. Beliefs about urban fringe forests among urban residents in Sweden. Urban Forestry and Urban Greening 11:321-328.

Eriksson, L., A.M. Nordlund and K. Westin. 2013 The general public's support for forest policy in Sweden: a value belief approach. Journal of Environmental Planning and Management 56(6): 850-867.

Fischer, J., D. J. Abson, V. Butsic, M. J. Chappell, J. Ekroos, J. Hanspach,T. Kuemmerle, H. G. Smith and H. Wehrden. 2014. Land sparing versus land sharing: moving forward. Conservation Letters 7(3): 149-157.

Gritten, D., B. Mola-Yudego, C. Delgado-Matas and J. Kortelainen. 2013. A quantitative review of the representation of forest conflicts across the world: resource periphery and emerging patterns. Forest Policy and Economics 33: 11-20.

Hemström, K., K. Mahapatra and L. Gustavsson. 2014. Public Perceptions and Acceptance of Intensive Forestry in Sweden. AMBIO 43: 196-206.

Jönsson, A. M., and Å. Gerger Swartling. 2014. Reflections on Science-Stakeholder Interactions in Climate Change Adaptation Research within Swedish Forestry. Society and Natural Resources 27(11): 1130-1144.

Kindstrand, C., J. Norman, M. Boman and L. Mattsson. 2008. Attitudes towards various forest functions: A comparison between private forest owners and forest officers. Scandinavian Journal of Forest Research 23(2): 133-136.

Kuhfeld, W.F. 2010. Marketing research methods in SAS experimental design, choice, conjoint, and graphical techniques.

Lidestav, G. and T. Nordfjell. 2005. A Conceptual Model for Understanding Social Practices in Family Forestry. Small-scale Forest Economics, Management and Policy 4(4): 391-408.

List, J., P. Sinha and M. Taylor. 2006. Using Choice Experiments to Value Non-Market Goods and Services: Evidence from Field Experiments. Advances in Economic Analysis and Policy 6(2): 1-37. Louviere, J. J., D. A. Hensher and J. Swait. 2000. Stated choice methods: analysis and application. Cambridge: Cambridge University Press.

Lämås, T. and C. Fries. 1995. Emergence of A Biodiversity Concept in Swedish Forestry Policy. Water, Air and Soil Pollution 82: 57-66.

Manski, C. 1977. The Structure of Random Utility Models. Theory and Decision 8: 229-254.

McFadden, D. 1974. Conditional Logit Analysis of Qualitative Choice Behavior. Academic Press, New York. 
McFadden, D. and K. Train. 2000. Mixed MNL Models for Discrete Response. Journal of Applied Econometrics 15: 447-470.

Nordlund, A. and K. Westin. 2011. Forest Values and Forest Management Attitudes among Private Forest Owners in Sweden. Forests 2: 30-50.

Nunes, P.A.L.D and J.C.J.M van den Bergh. 2001. Economic valuation of biodiversity: sense or nonsense? Ecological Economics 39: 203-222.

Ovaskainen, V., M. Neuvonen and E. Pouta. 2012. Modelling recreation demand with respondent-reported driving cost and stated cost of travel time: a Finnish case. Journal of Forest Economics 18(4): 303317.

Poe, G, E. Severance-Lossin, and M. Welsh. 1994. Measuring the Difference (X-Y) of Simulated Distribution: A Convolution Approach. American Journal of Agricultural Economics 76 (4): 90415.

Rogers, A. A. (2013). Public and expert preference divergence: Evidence from a choice experiment of marine reserves in Australia. Land Economics 89(2): 346-370.

Swedish Forest Agency. 2014. Swedish Statistical Yearbook of Forestry. Swedish Forest Agency, Jönköping

SÖDRA. 2014. Södrakubb av tall och grann - gäller för leverenasvirke från 1/8 2014. [Online] Available from: http://skog.sodra.com/sv/Salja-Virke/Virkesprislista/ [Accessed: $15^{\text {th }}$ of December 2014].

Train, K. 2009. Discrete choice methods with simulation. Cambridge university press.

Vermeulen, B., P. Good and M. Vandbroek. 2008. Models and optimal designs for conjoint choice experiments including a no-choice option. International Journal of Research in Marketing 25: 94-103. 


\section{Appendix}

Table A1. Descriptive statistics of the citizen and forest owner samples and the respective populations.

\begin{tabular}{|c|c|c|c|}
\hline & Citizens sample (\%) & $\begin{array}{c}\text { Population of Swedish } \\
\text { Citizen }^{24}(\%)\end{array}$ & $\begin{array}{c}H_{0}: \text { Sample }=\text { Population } \\
P \text {-values }\end{array}$ \\
\hline $\begin{array}{l}\text { Gender } \\
\text { Male } \\
\text { Female }\end{array}$ & $\begin{array}{l}47 \% \\
53 \%\end{array}$ & $\begin{array}{l}50 \% \\
50 \%\end{array}$ & 0.08 \\
\hline \multicolumn{4}{|l|}{ Age } \\
\hline 18-30 years & $13 \%$ & $21 \%$ & $<0.01$ \\
\hline 31-45 years & $19 \%$ & $25 \%$ & $<0.01$ \\
\hline 46-60 years & $25 \%$ & $25 \%$ & 0.94 \\
\hline $61-75$ years & $32 \%$ & $21 \%$ & $<0.01$ \\
\hline $75-84$ years & $11 \%$ & $8 \%$ & $<0.01$ \\
\hline \multicolumn{4}{|l|}{ Metropolitan location } \\
\hline Stockholm, Gothenburg and Malmö & $26 \%$ & $39 \%$ & $<0.01$ \\
\hline Other & $74 \%$ & $61 \%$ & \\
\hline \multicolumn{4}{|l|}{ Education } \\
\hline Completed 9 years & $19 \%$ & $24 \%$ & $<0.01$ \\
\hline Completed 12 years & $36 \%$ & $41 \%$ & $<0.01$ \\
\hline University education & $45 \%$ & $35 \%$ & $<0.01$ \\
\hline \multicolumn{4}{|l|}{ Income (EUR) ${ }^{a}$} \\
\hline Average disposable income per month & 3,170 EUR & 1,743 EUR & $<0.01$ \\
\hline \multirow[t]{2}{*}{ No. of observations ${ }^{b}$} & 1096 & 7511093 & \\
\hline & $\begin{array}{c}\text { Sample of forest owners } \\
(\%)\end{array}$ & $\begin{array}{c}\text { Population of forest } \\
\text { owners }^{25}(\%)\end{array}$ & \\
\hline $\begin{array}{l}\text { Gender } \\
\text { Male } \\
\text { Female }\end{array}$ & $\begin{array}{l}79 \% \\
21 \%\end{array}$ & $\begin{array}{l}62 \% \\
38 \%\end{array}$ & $<0.01$ \\
\hline \multicolumn{4}{|l|}{ Age } \\
\hline 18-30 years & $1 \%$ & $2 \%$ & $<0.01$ \\
\hline 31-45 years & $8 \%$ & $24 \%$ & $<0.01$ \\
\hline 46-60 years & $26 \%$ & $37 \%$ & $<0.01$ \\
\hline $61-75$ years & $52 \%$ & $24 \%$ & $<0.01$ \\
\hline $75-84$ years & $13 \%$ & $13 \%$ & 0.83 \\
\hline \multicolumn{4}{|l|}{ Large forest owners $>200$ ha } \\
\hline Yes & $13 \%$ & $4 \%$ & $<0.01$ \\
\hline No & $87 \%$ & $96 \%$ & \\
\hline \multicolumn{4}{|l|}{ Resident forest owner $^{b}$} \\
\hline Yes & $73 \%$ & $68 \%$ & $<0.01$ \\
\hline No & $27 \%$ & $32 \%$ & \\
\hline \multicolumn{4}{|l|}{ Member in a Forest owners' association } \\
\hline Yes & $52 \%$ & $34 \%$ & $<0.01$ \\
\hline No & $48 \%$ & $66 \%$ & \\
\hline No. of observations ${ }^{b}$ & 2398 & 329541 & \\
\hline
\end{tabular}

Notes: ${ }^{a}$ The average income for the sample is generated from categorical data where the mean of each category is used.

${ }^{b}$ There is some variation in number of observations due to missing values in some variables for the samples. ${ }^{b}$ Resident forest owners are those who live in the municipality where their forestry property is located. ${ }^{c}$ T-test for continuous variables and binomial probability test for binary variables and for each category in categorical variables.

${ }^{24}$ Data from Statistics Sweden 2013, http://www.scb.se/en _/.

${ }^{25}$ Data from Swedish Forest Agency (2014). 
Table A2. Estimation results of random parameter logit models with socio-economic characteristics; standard errors in parentheses.

\begin{tabular}{|c|c|c|c|}
\hline Parameters & Citizens & Forest owners & Forest officials \\
\hline Forest age and structure & $-0.076(0.252)$ & $-1.402 * * *(0.396)$ & $-1.065(0.780)$ \\
\hline Composition of trees & $0.553^{* * *}(0.211)$ & $0.962 * * *(0.285)$ & $0.494(0.594)$ \\
\hline Total number of forest bird species & $0.363 *(0.187)$ & $0.489 * *(0.225)$ & $0.544(0.511)$ \\
\hline Number of rare forest bird species & $0.656 * * *(0.195)$ & $0.689 * * *(0.238)$ & $-0.102(0.581)$ \\
\hline Geographical spread of biodiversity & $0.096(0.249)$ & $-0.433(0.326)$ & $-0.033(0.768)$ \\
\hline Cost & $-0.005 * * *(0.001)$ & $0.003(0.002)$ & $-0.005(0.005)$ \\
\hline \multicolumn{4}{|l|}{ Interaction parameters } \\
\hline Forest age and structure*Male & $-0.023(0.137)$ & $-0.651 * * *(0.168)$ & $-0.312(0.397)$ \\
\hline Composition of trees*Male & $0.020(0.114)$ & $-0.234 *(0.122)$ & $-0.412(0.321)$ \\
\hline Total number of forest bird species*Male & $0.169 *(0.099)$ & $-0.043(0.095)$ & $-0.424(0.266)$ \\
\hline Number of rare forest bird species*Male & $-0.099(0.102)$ & $-0.208^{* *}(0.100)$ & $-0.109(0.298)$ \\
\hline Geographical spread of biodiversity*Male & $0.093(0.132)$ & $-0.195(0.139)$ & $-0.502(0.414)$ \\
\hline Cost*Male & $<0.001(0.001)$ & $-0.001(0.001)$ & $0.002(0.002)$ \\
\hline Forest age and structure*Age & $0.003(0.004)$ & $0.024 * * *(0.006)$ & $0.013(0.012)$ \\
\hline Composition of trees*Age & $0.009 * * *(0.003)$ & $0.013^{* * *}(0.004)$ & $0.014(0.008)$ \\
\hline Total number of forest bird species*Age & $-0.005 *(0.003)$ & $-0.006 *(0.003)$ & $0.006(0.007)$ \\
\hline Number of rare forest bird species*Age & $-0.002(0.003)$ & $-0.004(0.004)$ & $0.005(0.008)$ \\
\hline Geographical spread of biodiversity*Age & $-0.001(0.004)$ & $0.009 *(0.005)$ & $-0.004(0.011)$ \\
\hline Cost*Age & $<0.001(<0.001)$ & $<-0.001 * * *(<0.001)$ & $<-0.001(<0.001)$ \\
\hline Forest age and structure*Education & $0.375^{* * *}(0.142)$ & $-0.200(0.141)$ & $-0.585(0.390)$ \\
\hline Composition of trees*Education & $0.377^{* * *}(0.118)$ & $-0.148(0.104)$ & $0.008(0.291)$ \\
\hline Total number of forest bird species*Education & $0.207 * *(0.102)$ & $0.203 * *(0.082)$ & $-0.347(0.257)$ \\
\hline Number of rare forest bird species*Education & $0.235^{* *}(0.105)$ & $0.128(0.086)$ & $0.247(0.293)$ \\
\hline Geographical spread of biodiversity*Education & $0.180(0.135)$ & $0.070(0.119)$ & $-0.107(0.373)$ \\
\hline Cost*Education & $-0.001(0.001)$ & $-0.001(0.001)$ & $-0.002(0.002)$ \\
\hline Forest age and structure*Urban & $0.202(0.140)$ & $-0.026(0.161)$ & $-0.053(0.319)$ \\
\hline Composition of trees*Urban & $-0.072(0.116)$ & $0.022(0.117)$ & $0.058(0.240)$ \\
\hline Total number of forest bird species*Urban & $0.066(0.101)$ & $0.037(0.093)$ & $0.173(0.220)$ \\
\hline Number of rare forest bird species*Urban & $0.017(0.104)$ & $0.063(0.097)$ & $0.447 *(0.268)$ \\
\hline Geographical spread of biodiversity*Urban & $0.092(0.134)$ & $-0.236 *(0.135)$ & $0.103(0.312)$ \\
\hline Cost*Urban & $0.001(0.001)$ & $-0.001(0.001)$ & $-0.005^{* *}(0.002)$ \\
\hline \multicolumn{4}{|l|}{ Standard deviation } \\
\hline Age and structure & $1.016^{* * *}(0.127)$ & $1.902^{* * *}(0.110)$ & $1.013^{* * *}(0.215)$ \\
\hline Composition of tree species & $1.108 * * *(0.086)$ & $1.346 * * *(0.077)$ & $0.783 * * *(0.135)$ \\
\hline Total number of forest bird species & $0.797^{* * *}(0.072)$ & $0.742^{* * *}(0.059)$ & $0.349 * *(0.158)$ \\
\hline Number of rare forest bird species & $0.812^{* * *}(0.081)$ & $0.904 * * *(0.067)$ & $0.695 * * *(0.148)$ \\
\hline Geographical spread of biodiversity & $0.727^{* * *}(0.126)$ & $1.139 * * *(0.091)$ & $0.611^{* * *}(0.231)$ \\
\hline No. of individuals & 1032 & 2118 & 293 \\
\hline No. of observations & 6101 & 12458 & 1745 \\
\hline Log-Likelihood & -3683.6 & -7098.1 & -963.6 \\
\hline $\mathrm{R}^{2}$ (constants only) & 0.129 & 0.178 & 0.202 \\
\hline
\end{tabular}


Table A3. Backward stepwise estimation results of multinomial logit models where choice attribute preferences are modeled as linear functions of respondents' background characteristics; standard errors in parentheses.

\begin{tabular}{|c|c|c|c|}
\hline & Citizens & Forest owners & Forest officials \\
\hline \multicolumn{4}{|l|}{ Means parameters } \\
\hline Forest age and structure & $0.168 * * *(0.063)$ & $-0.818^{* * *}(0.166)$ & $-0.789 * * *(0.234)$ \\
\hline Composition of trees & $0.084(0.099)$ & $0.305^{* * *}(0.115)$ & $-0.108(0.266)$ \\
\hline Total number of forest bird species & $0.011(0.056)$ & $-0.077 *(0.043)$ & $-0.016(0.062)$ \\
\hline Number of rare forest bird species & $0.224 * * *(0.058)$ & $0.208^{* * *}(0.037)$ & $0.091(0.074)$ \\
\hline Geographical spread of biodiversity & $0.119 * * *(0.046)$ & $-0.421^{* *}(0.201)$ & $-0.123(0.255)$ \\
\hline Cost & $-0.005^{* * *}(<0.001)$ & $0.002^{* *}(<0.001)$ & $-0.002 * * *(<0.001)$ \\
\hline \multicolumn{4}{|l|}{ Interaction parameters } \\
\hline Forest age and structure*Male & & $-0.241^{* * *}(0.069)$ & \\
\hline Total number of forest bird species*Male & $0.099 * *(0.048)$ & & \\
\hline Geographical spread of biodiversity*Male & & & $-0.470 *(0.263)$ \\
\hline Cost*Male & & $-0.001 * * *(<0.001)$ & \\
\hline Forest age and structure*Age & & $0.014^{* * *}(0.003)$ & \\
\hline Composition of trees*Age & $0.006^{* * *}(0.002)$ & $0.007^{* * *}(0.002)$ & $0.008 *(0.005)$ \\
\hline Geographical spread of biodiversity*Age & & $0.005 *(0.003)$ & \\
\hline Cost*Age & & $<-0.001 * * *(<0.001)$ & \\
\hline Forest age and structure*University education & $0.155 *(0.079)$ & & $-0.925 * * *(0.299)$ \\
\hline Composition of trees*University education & $0.138 * *(0.054)$ & & \\
\hline Number of rare forest bird species*Urban & & & $0.340 *(0.175)$ \\
\hline Geographical spread of biodiversity*Urban & & $-0.129 * *(0.066)$ & \\
\hline Cost*Urban & $<0.001 *(<0.001)$ & & $-0.002 * *(0.001)$ \\
\hline $\begin{array}{l}\text { Forest age and structure*Employee } \\
\text { E. }\end{array}$ & $-0.167 * *(0.078)$ & & \\
\hline Number of rare forest bird species*Employee & & $0.099 * *(0.044)$ & \\
\hline Geographical spread of biodiversity*Employee & & $0.134 *(0.071)$ & \\
\hline Total number of forest bird species* Income & & $0.005^{* * *}(0.001)$ & \\
\hline Cost* Income & $<0.001^{* * *}(<0.001)$ & & \\
\hline Composition of trees*Familiarity with forest & $0.252^{* * *}(0.061)$ & & \\
\hline Total number of forest bird species*Familiarity with forest & $0.120 * *(0.056)$ & & \\
\hline Number of rare forest bird species*Familiarity with forest & $0.145^{* *}(0.064)$ & & \\
\hline $\begin{array}{l}\text { Forest age and structure*Large forest owner } \\
\text {. }\end{array}$ & & $-0.388^{* * *}(0.087)$ & \\
\hline Composition of trees*Large forest owner & & $-0.155^{* * *}(0.058)$ & \\
\hline Number of rare forest bird species*Large forest owner & & $0.146 * *(0.062)$ & \\
\hline $\begin{array}{l}\text { Forest age and structure*Forest association member } \\
\text {. }\end{array}$ & & $-0.164 * * *(0.056)$ & \\
\hline Cost*Forest association member & & $<-0.001 * * *(<0.001)$ & \\
\hline Number of rare forest bird species* Inherited property & & $-0.095^{* *}(0.040)$ & \\
\hline Forest age and structure*Forest related education & & & $0.535 *(0.286)$ \\
\hline Composition of trees*Forest related education & & & $0.251 *(0.141)$ \\
\hline Forest age and structure*Public official & & & $0.735^{* * *}(0.162)$ \\
\hline Composition of trees* Public official & & & $0.340 * * *(0.116)$ \\
\hline Total number of forest bird species* Public official & & & $0.360^{* * *}(0.103)$ \\
\hline Number of rare forest bird species* Public official & & & $0.386 * * *(0.121)$ \\
\hline No. of observations & 5200 & 10391 & 1709 \\
\hline Log-Likelihood & -3244.6 & -6299.2 & -937.0 \\
\hline Pseudo R ${ }^{2}$ (adjusted) & 0.097 & 0.124 & 0.200 \\
\hline
\end{tabular}


